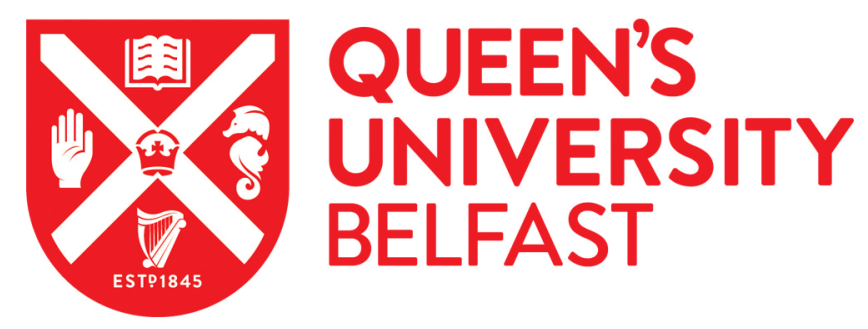

\title{
Moral emotions and the politics of blame and credit during transitional justice moments
}

Hearty, K. (2018). Moral emotions and the politics of blame and credit during transitional justice moments. International Journal of Transitional Justice. https://doi.org/10.1093/ijtj/ijy027

Published in:

International Journal of Transitional Justice

\section{Document Version:}

Peer reviewed version

Queen's University Belfast - Research Portal:

Link to publication record in Queen's University Belfast Research Portal

Publisher rights

(C) The Author 2018. Published by Oxford University Press. This work is made available online in accordance with the publisher's policies. Please refer to any applicable terms of use of the publisher.

\section{General rights}

Copyright for the publications made accessible via the Queen's University Belfast Research Portal is retained by the author(s) and / or other copyright owners and it is a condition of accessing these publications that users recognise and abide by the legal requirements associated with these rights.

Take down policy

The Research Portal is Queen's institutional repository that provides access to Queen's research output. Every effort has been made to ensure that content in the Research Portal does not infringe any person's rights, or applicable UK laws. If you discover content in the Research Portal that you believe breaches copyright or violates any law, please contact openaccess@qub.ac.uk. 


\title{
Moral emotions and the politics of blame and credit during transitional justice moments
}

\begin{abstract}
This article critically examines how moral emotions are intrinsically tied to the process of apportioning blame and credit in post-conflict societies. In doing so, it draws out the complexity that underpins moral emotions during key junctures in transitional justice. Recognising that moral emotions naturally stem from the making of a judgement about a 'target', the article argues that the relationship between those experiencing the moral emotion and the 'target' fundamentally determines whether the 'target' becomes the object of blame or credit during seminal moments of transition. Through using a focused empirical case study, the article identifies why and how changes over time in the relationships between the 'judgemental self' and the 'target', in personal and political identities, and in perceptions of what is and is not moral influences the moral emotions expressed by different versions of the 'judgemental self' towards the 'target'.
\end{abstract}

\section{Keywords:}

Moral emotions, transitional justice, victims, spoilers

\section{Introduction}

I have told Arlene Foster that I have tendered my resignation effective from 5 o'clock today... I believe today is the right time to call a halt to the DUP's arrogance... We will not be re-nominating for the position of Deputy First Minister. ${ }^{1}$

With these words Sinn Fein's Martin McGuinness signalled the collapse of the consociational powersharing institutions in the North of Ireland. Sparked by fallout over Democratic Unionist Party (DUP) resistance to an inquiry into a controversial renewable heating scheme, the resignation brought an end to Northern Ireland's lengthiest period of uninterrupted devolved powersharing.

\footnotetext{
1 'Martin McGuinness resigns as NI deputy first minister', BBC, 10 January 2017, http://www.bbc.co.uk/news/uk-northern-ireland-38561507 (accessed 20 March 2017).
} 
Visibly frail, media attention quickly turned from the message to the messenger. His ill-health worsened, causing him to retire rather than contest the March 2017 elections triggered by his resignation. McGuinness was the last of the Good Friday Agreement (GFA) era figureheads to exit electoral politics in Northern Ireland. He eventually succumbed to ill-health on 21 March $2017 .{ }^{2}$ His retirement and subsequent death evoked emotive commentary from various quarters, with many focusing on his personal and political transition from armed struggle to peaceful politics. During his tenure as Northern Ireland's Deputy First Minister, McGuinness was involved in several of what Mark Drumbl labels 'transitional justice moments' when something of significance happens in a society's 'moving on' process. ${ }^{3}$ His own retirement and passing might too be interpreted through such a lens; a pivotal figure that had fought the conflict yet helped bring it to an end was being replaced by Michelle O'Neill, a new breed of post-conflict politician.

This article draws on the extensive media coverage of Martin McGuinness' retirement and death to critically evaluate the nexus between moral emotions and 'transitional justice moments'. As emotions arise in response to perceived changes, threats or opportunities in the world, ${ }^{4}$ they have a particular relevance to 'transitional justice moments' that are defined by changes in relationships, opportunities for further change and threats to old certainties. Given that many of the goals of transitional justice like truth, reconciliation and justice remain contested and poorly defined, ${ }^{5}$ there is a particular case for using 'transitional justice moments' to critically examine 'moral emotions' that have been conceptualised as a moral judgment invoked by a particular moral situation. ${ }^{6}$ In short, they are a judgement of what is right and wrong, what is good and bad and what is just and

\footnotetext{
2 'Sinn Fein's Martin McGuinness dies aged 66', BBC, 21 March 2017, http://www.bbc.co.uk/news/uk-northernireland-39185899 (accessed 21 March 2017).

${ }^{3}$ Mark Drumbl, 'Transitional Justice Moments', International Journal of Transitional Justice, 10 (2) (2016): 203 -210 .

${ }^{4}$ Jonathan Haidt, 'The Moral Emotions' in R Davidson, K Scherer \& H Goldsmith (eds.) Handbook of affective sciences (Oxford: Oxford University Press, 2003), pp. 852 - 870, 853.

${ }^{5}$ Tristan Anne Borer, 'Truth Telling as a peacebuilding activity: a theoretical overview' in Tristan Anne Borer (ed) Telling the Truths: Truth Telling, and Peace Building in Post-conflict Societies (Indiana: University of Notre Dame Press, 2006), 3.

${ }^{6}$ Kurt Grey \& Daniel Wegner, 'Dimensions of moral emotions', Emotion Review, (2011) 3(3): 258 - 260.
} 
unjust in that moral situation, ${ }^{7}$ signalling either approval or disapproval of certain actors and their actions. ${ }^{8}$ Whether any individual approves or disapproves of 'transitional justice moments' rests on myriad factors including how they consciously and unconsciously evaluate that moment, to who or what they attribute responsibility for that moment, their expectations in that particular situation, their identity at that given moment and their identity in relation to other persons or groups also relevant to that moment. ${ }^{9}$ Further complexity is added by the fact that perceptions of morality can change over time in response to new contexts. ${ }^{10}$ What or who is approved or disapproved of during conflict might then be very different from that which is approved or disapproved of during the process of trying to address the legacy of that conflict. Accordingly, there are different vantage points from which 'moving on' processes can either be approved or disapproved of depending on group identities, changing individual perceptions of morality, and social relationships. The often unprecedented nature of 'transitional justice moments' leaves them lacking 'feelings rules' on what moral emotions can or should be expressed towards certain actors. ${ }^{11}$ That is, whether it is right or wrong, or good or bad to approve or disapprove of 'moving on' with former adversaries remains contested. Using the empirical case of McGuinness during 'transitional justice moments', then, not only furthers our understanding of emotion within the field of transitional justice but can also enrich the existing academic literature on emotion by further nuancing identity theories, exchange theories and justice theories. ${ }^{12}$

This article uses an innovative theoretical synthesis of previously unconnected frameworks found in recent works on emotion and transitional justice. It marries Mihaela Mihai's conceptualisation of

\footnotetext{
${ }^{7}$ Renée Jeffery, 'The forgiveness dilemma: emotions and justice at the Khmer Rouge tribunal', Australian Journal of International Affairs, 69 (1) (2015): 35 - 52.

${ }^{8}$ Eduardo Bericat, 'The sociology of emotions: Four decades of progress', Current Sociology, 64 (3) (2016): 491

-513 .

${ }^{9}$ Ibid.

${ }^{10}$ Gabriel Abend, 'What's New and What's Old about the New Sociology of Morality' in Steven Hitlin \& Stephen Vaisey (eds.) Handbook of the Sociology of Morality (New York: Springer, 2010), 561 - 584.

${ }^{11}$ Arlie Hothschild, 'Emotion work: Feeling rules and social structure', American Journal of Sociology, (1979) 85 (3): $551-575$.

12 Jan Stets, 'Current Emotion Research in Sociology: Advances in the Discipline', Emotion Review, 4 (3) (2012): $326-334$.
} 
emotion as a judgement comprising of 'instigation' (the cause of the emotional response), a 'target' (the person/thing judgement is directed at) and an 'objective' (the desired outcome of an emotional response) with Ruth Jamieson's observation that transitional justice, in the North of Ireland at least, is 'inescapably about the politics of credit and blame' ${ }^{13}$ Developing this further, it posits that the moral emotions felt towards the 'target' during 'transitional justice moments' become contingent on the proximity or distance between where the 'judgemental self' (ie the person experiencing moral emotions) is plotted and where the 'target' is plotted on their imagined politico-moral spectrum. When these positions change, the article argues, so too will the 'instigation'. Changing 'instigation' in turn conditions whether the 'objective' is to attribute blame or credit. With morality operating to a logic whereby those who do good are credited while those who do bad are blamed, ${ }^{14}$ any given moral emotion is essentially a reactive judgement that feeds off the conduct and/or treatment of the 'target' during 'transitional justice moments'. When this is approved of 'credit' is afforded, yet when it is disapproved of 'blame' is instead attributed. Building from here, the article then applies this theory to the paradox of how McGuinness was 'morally typecast' during 'transitional justice moments' 15 ; as an unrepentant 'terrorist', as a traitor, as a peacemaker and as a 'struggle hero'.

\section{Moral emotions and transitional justice}

Academic literature on emotions draws from neuroscientific, psychological, social scientific and sociological perspectives. ${ }^{16}$ Emotion has been understood as reactive brain activity to some external stimulus, as a cognitive process, and as a macro-level socio-cultural phenomenon. ${ }^{17}$ This scholarship has also differentiated between primary emotions which are thought to be universal and biologically

\footnotetext{
${ }^{13}$ Mihaela Mihai, Negative Emotions and Transitional Justice (New York: Columbia University Press, 2016), 64; Ruth Jamieson, 'Framing Blame and Victimhood in Post-conflict Northern Ireland' in The Palgrave Handbook of Criminology and War, eds. Ross McGarry and Sandra Walklate (London: Palgrave MacMillan, 2016), 169-187.

${ }^{14}$ Elliot Turiel, The development of social knowledge: Morality and convention (Cambridge: Cambridge University Press, 1983).

${ }^{15}$ Grey \& Wegner, supra $\mathrm{n} 6$.

${ }^{16}$ Jonathan Turner, 'The Sociology of Emotions: Basic Theoretical Arguments', Emotion Review, 1 (4) (2009):

$340-354$.

${ }^{17}$ Robert Roberts, Emotions: An essay in Aid of Moral Psychology (Cambridge: Cambridge University Press, 2003), 4.
} 
innate, and secondary emotions believed to be socially and culturally constructed. ${ }^{18}$ While psychologists might seek to understand how emotions are linked to personality, paying particular attention to the processes of moral and affective reasoning whereby individuals internalise certain norms into their own behaviour, ${ }^{19}$ sociologists, on the other hand, theorise and test the relationship among key macroelements (social structure and culture), microlements (interaction and selfprocesses) and individual experiences. ${ }^{20}$ Common to both fields is a 'turn' to emotion and morality that has birthed some nuanced approaches to complex phenomena like moral emotions that were traditionally overlooked. ${ }^{21}$ This 'turn' to emotion and morality has been discernible in social science too, ${ }^{22}$ with recent studies examining the role of love, compassion, empathy and disgust in contexts as diverse as the criminal justice system, ${ }^{23}$ political events, ${ }^{24}$ charity marketing campaigns, ${ }^{25}$ war crimes tribunals ${ }^{26}$ and social movement mobilisation. ${ }^{27}$

Transitional justice has also seen a growing body of work on emotion emerge. ${ }^{28}$ In light of the social scientific 'turn' to emotion such a vein of scholarship is perhaps unsurprising given that transitional justice encompasses the release of prisoners, the granting of amnesties, the issuing of apologies, the holding of trials and sometimes even the election to political office of those formerly engaged in

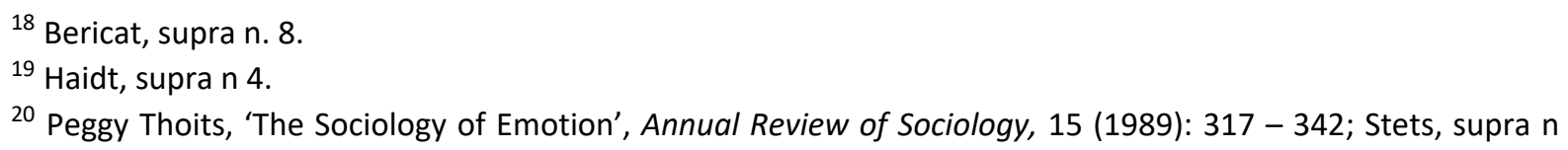


conflict. ${ }^{29}$ Because moral emotions are invariably about someone or something, ${ }^{30}$ these processes, and the actors involved in them, can be morally judged from the perspective of both victim and victimiser. ${ }^{31}$ Although understood at the most basic level as judgements of what is right and what is wrong, more recent studies on moral emotions have further nuanced the concept in a way that can aid the understanding of emotions during transitional justice processes. For instance, moral emotions can be positive or negative - that is the 'instigation' may arise from adherence to or violation of an imagined moral code. They can also be directed at others or at the self. They can be 'self-critical' in that they are directed at oneself for violating the moral code or they can be 'othercritical' in that they are directed at others for their violation of it. Likewise, they can be 'othersuffering' in that they relate to witnessing another experience something bad or they can be 'otherpraising' in that they result from having seen someone do something good. ${ }^{32}$

Moral emotions can be dispersed individually and collectively. On the one hand, this means that they may be vicariously directed at a 'target' on the basis of their association with a particular grouping rather than for any particular action on their own part. ${ }^{33}$ In this instance a high profile figure like McGuinness becomes the 'target' for negative moral emotions directed more generally at Irish republicans by the Irish Republican Army's (IRA) victims, and also for those more generally directed at the Sinn Fein leadership by critical spoilers within Irish republicanism. At the same time, though, someone like McGuinness can also be judged for their own actions as opposed to those of their group more generally. The attribution of blame and credit becomes clouded in the case of

\footnotetext{
${ }^{29}$ Ruti Teitel, Transitional Justice (Oxford: Oxford University Press, 2000); Jon Elster, Closing the Books: Transitional Justice in Historical Perspective (Cambridge: Cambridge University Press, 2004); Louise Mallinder and Kieran McEvoy eds, Transitional Justice: Origins, boundaries and methods in transitional justice (London: Routledge, 2016); Giada Girelli, Understanding Transitional Justice: A Struggle for Peace, Reconciliation and Rebuilding (New York: Springer, 2017).

${ }^{30}$ Emma Hutchison and Roland Bleiker, 'Emotional Reconciliation: Reconstituting Identity and Community after Trauma', European Journal of Social Theory, 11 (3) (2008): 385 - 403.

${ }^{31}$ Karstedt, supra $\mathrm{n} 28$.

32 Jonathan Turner and Jan Stets, 'Moral Emotions' in Handbook of Sociology of Emotions eds., Jan Stets \& Jonathan Turner (New York: Springer, 2006), 544 - 566, 550.

${ }^{33} \mathrm{lbid}, 551$.
} 
McGuinness who despite being one of the 'drivers' of transition, ${ }^{34}$ also had a much publicised role in the conflict too. As Brewer notes, here the moral-emotional calculation rests not only on what people did during the conflict but also what they are doing after it. ${ }^{35}$ To that end, moral emotions can be 'future focused' when concentrating on a better future or they can be 'past focused' when negative emotion from the past is carried into transition. ${ }^{36}$ Whether the 'judgemental self' judges the 'target' on what they did during the conflict or whether they make that judgement according to what the 'target' has done/ is doing after the conflict determines whether the 'objective' is attributing them blame or credit. Transition also creates emotional friction between loyalty to the past (as manifest as loyalty to lost ideals, victims and dead comrades) and loyalty to the future (which manifests as subscribing to a new peaceful dispensation). ${ }^{37}$ Just as with 'past focused' and 'future focused' emotions, loyalty to the past or loyalty to the future will subsequently shape the 'instigation' for judging the 'target' and the 'objective' of attributing blame or credit.

\section{Relationships, moral emotions and change}

To add further complexity, moral emotions are relational ${ }^{38}$ - meaning they are the product of some interaction between various parties. ${ }^{39}$ This means that emotion is conditioned by the relationship between the person(s) experiencing the emotion and the person(s) it is directed at. ${ }^{40}$ Relationships can, of course, change over time. So too can identities and perceptions of morality. This is particularly relevant during 'transitional justice moments' given that the entire premise of

\footnotetext{
${ }^{34}$ Elster, supra $\mathrm{n} 29$.

${ }^{35}$ Brewer, supra n 28, 106.

${ }^{36}$ John Brewer, 'Guilt, Righteous Anger and Forgiveness as Issues in Transitional Justice', paper presented at 'Transitional Justice, the Legacy of Guilt and the Question of Punishment' University of Warwick 4 March 2016, http://pure.qub.ac.uk/portal/en/publications/guilt-righteous-anger-and-forgiveness-as-issues-in-transitionaljustice(ee1dcde9-cb36-4747-9682-6926e43b1431).html (accessed 23 October 2017).

${ }^{37}$ Lawther, supra $\mathrm{n} 28$.

38 Elster, supra n 28.

${ }^{39}$ Eva van Roekel, 'Accessing emotions through humour in the contemporary Argentinean transitional justice trajectory', The Unfamiliar, 3 (1) (2013): $24-33$.

${ }^{40}$ Elster, supra n 29, 217.
} 
transitional justice is built around the notion of change; changed political constellations, ${ }^{41}$ changing individual and collective relationships ${ }^{42}$ and changing identities. ${ }^{43}$ This multi-level and multi-form change has a paradoxical influence on existing and emerging relationships. On the one hand it can lead to the erosion of previously tight-knit relationships within identifiable 'ingroups' that were formerly bound together by the pressures of conflict, yet on the other hand it can lead to a reconfiguration of relationships with elements of the 'outgroup' that are in favour of the transitional process. ${ }^{44}$ In short, 'transitional justice moments' can transform longstanding political comrades into political opponents while at the same time turning what were once political enemies into transitional justice fellow travellers. Moral emotions change in tandem with this as the politicomoral location of the 'judgemental self' changes (or not) in accordance with the circumstances too. ${ }^{45}$ During 'transitional justice moments' the 'instigation' underpinning any given moral emotion is contingent upon how the 'judgemental self' was politically and morally positioned in relation to the 'target' in the past and where they are politically and morally positioned to the 'target' in the present. Whenever and wherever there is movement in this positioning on the imagined politicomoral spectrum, the moral emotion will change accordingly. The logical inference here is that as proximity to the 'target' increases so too does positive moral emotions and the willingness to attribute credit, while conversely as the distance from the 'target' increases so too does negative moral emotions and the need to attribute blame.

It is advisable at this juncture to highlight how this applies to Martin McGuinness whose transition from being a senior IRA commander in Derry to Deputy First Minister in the powersharing executive

\footnotetext{
${ }^{41}$ van Roekel, supra n 39.

42 Judy Baraslou, Trauma and Transitional Justice in Divided Societies (Washington DC: USIP Press, 2008); Wendy Lambourne, 'Transitional justice and peacebuilding after mass violence', International Journal of Transitional Justice, 3 (1) (2009): $28-48$.

43 Jonathan Sisson, 'A Conceptual Framework for Dealing with the Past', Politorbis, 50 (3): 11; Nevin Aiken, 'Learning to live together: Transitional justice and intergroup reconciliation in Northern Ireland', International Journal of Transitional Justice, 4 (2) (2010): 166 - 188.

${ }^{44}$ Kevin Hearty, Critical Engagement: Irish Republicanism, Memory Politics and Policing (Liverpool: Liverpool University Press, 2017).

${ }^{45}$ Martha Nussbaum, Hiding from humanity: Disgust, shame and the law (New Jersey: Princeton University Press, 2009)
} 
was 'once deemed unthinkable' ${ }^{46}$ This transition generated complicated moral emotion rooted relationships with a number of constituencies. In the first instance there is his relationship with those who can be labelled rejecters of transition; those who are differentially positioned to McGuinness on accepting transition. Their current positional relationship with McGuinness is one of distance along their imagined politico-moral spectrum. This group can be further divided in terms of where they were previously positioned to McGuinness. On the one hand, there are some victims of IRA violence who have always had a relationship of distance. Their moral emotions are shaped by a worldview that delegitimises both the transition and Irish republican political violence. Their relationship can be defined as an unchanged relationship with McGuinness as blameworthy 'terrorist'. On the other hand there are former comrades of McGuinness in various violent and nonviolent Irish republican spoiler groups who have gone from having a relationship of proximity to now having one of distance. Their moral emotions are conditioned by a worldview that seeks to delegitimise the transition rather than political violence. Their relationship can be understood as a newly distant relationship with McGuinness as blameworthy traitor. These relationships are characterised by negative moral emotions that are 'past focused', grounded in loyalty to the past and predicated on an 'objective' of attributing blame to McGuinness.

There are those who can be labelled as accepters of transition; in short those who, like McGuinness, accept the process of transition. Again, it is possible to further divide this group depending on where they were previously positioned. On the one hand there are some victims of IRA violence who have transformed a previous relationship of distance into one of proximity. Their moral emotions are shaped by a worldview that disapproves of McGuinness' past even though they came to share common ground with him as a transitional justice fellow traveller. While not exonerating McGuinness from blame for the conflict, they are prepared to at least afford him credit based on his final position on the imagined politico-moral spectrum. Their relationship is an increasingly

\footnotetext{
46 'Back home in Derry: Martin McGuinness retires', Eolas, 10 March 2017, http://www.eolasmagazine.ie/back-home-derry-martin-mcguinness-retires/ (accessed 15 March 2017).
} 
proximate one with McGuinness as creditable peacemaker. By contrast, there are longstanding comrades of McGuinness who always had a relationship of proximity with him. They have been constantly positioned beside McGuinness on their imagined politico-moral spectrum during conflict and transition. Unlike those mentioned previously, they afford McGuinness credit for where his transition started and where it ended. Their relationship is therefore an unchanged one with McGuinness as elevated struggle hero.

Before critically examining each of the relationships, though, it is necessary to briefly examine how McGuinness fulfilled his role as 'driver' of transition. Accordingly, this will provide an insight into his moral-emotional conduct while, to borrow a phrase from McEvoy and McGregor, ${ }^{47}$ 'doing' transitional justice. In doing so, it is possible to examine how he played into the various roles he was 'morally typecast' in, demonstrating further the nexus between emotions and existing expectations. ${ }^{48}$ That is, how in 'doing' transitional justice McGuinness confirmed himself as an unrepentant 'terrorist', traitor, peacemaker and 'struggle hero' to various audiences.

\section{McGuinness 'doing' transitional justice}

To understand McGuinness 'doing' transitional justice it is necessary to fully appreciate his past. By his own admission, McGuinness was a senior IRA commander in Derry during the early 1970s. Some sources contend, however, that he also held several other prominent positions within both the IRA and Sinn Fein throughout the conflict. ${ }^{49}$ While appearing at the Special Criminal Court in Dublin in 1973 he told the judge 'I have been a member of the Derry IRA for two years and I am very, very proud of it'. ${ }^{50}$ Far from revising this during transition, McGuinness reasserted in 2015 that he was

\footnotetext{
${ }^{47}$ Kieran McEvoy \& Lorna McGregor eds., Transitional Justice from below: Grassroots activism and the struggle for change (London: Bloomsbury, 2008).

48 Jonathan Turner \& Jan Stets, 'Sociological theories of human emotions', Annual Review of Sociology, 32 (2006): $25-52$.

${ }^{49}$ Ed Moloney, A Secret History of the IRA (London: Penguin, 2002).

50 'McGuinness should tell his story and set record straight to help victim families', accessed via http://campus.ie/surviving-college/mcguinness-should-tell-his-story-and-set-record-straight-help-victimfamilies (accessed 27 January 2017).
} 
'proud' to have been in the IRA. ${ }^{51}$ However, in being a 'driver' of transition he was integral to persuading most, though not all, Irish republicans to accept the peace process and to subsequently work the process of transition that followed. Accordingly, McGuinness; served as Minister for Education and then as Deputy First Minister in the power-sharing executive, stood with Unionist political leaders and the then Police Service of Northern Ireland (PSNI) Chief Constable to publicly condemn spoiler violence, engaged with the British monarchy in the spirit of outreach to Unionists, and engaged in reflectively self-critical discussions with victims of the IRA. Throughout all of these endeavours McGuinness never hid nor disavowed his IRA past but nonetheless argued that 'I was once in the IRA. I am now a peacebuilder. I don't expect anyone to take me at my word. I expect them to take me at my deeds'. ${ }^{52}$ For McGuinness this meant showing that 'my war is over' ${ }^{53}$ and that he was 'someone who lives in the here and now for the future who wants to build a better future'. ${ }^{54}$

One way that McGuinness sought to have people take him by his 'deeds' was through engaging with those victimised by the IRA. On a practical level, he personally intervened and appealed for those with information on a number of victims disappeared by the IRA (commonly known as 'the Disappeared ${ }^{\prime 55}$ ) to help the families retrieve their loved ones remains. ${ }^{56}$ Perhaps, though, it was his engagements on a symbolic level that were more significant in recalibrating the moral emotional relationship he shared with some of them. In public engagements with IRA victims McGuinness expressed regret for the actions of the IRA, acknowledged the hurt they had caused their victims and spoke of his willingness to not only repair this hurt but to consign such hurtful violence to the history

\footnotetext{
51 'Martin McGuinness 'proud' of his IRA past', Derry Journal, 12 October 2015, http://www.derryjournal.com/news/martin-mcguinness-proud-of-his-ira-past-1-7006716 (accessed 3 November 2017).

52 'Interview with Martin McGuinness \& Colin Parry', Right Word Comms, http://rightwordcomms.co.uk/interview-with-martin-mcguinness-colin-parry/ (accessed 20 March 2017 ). ${ }^{53} B B C$, supra n. 2.

54 'Defiant McGuinness defends his IRA past', JOE.ie, https://www.joe.ie/uncategorized/defiant-mcguinnessdefends-his-ira-past-27639 (accessed 6 November 2017).

55 Lauren Dempster, 'The Republican Movement, 'Disappearing', and Framing the Past in Northern Ireland', International Journal of Transitional Justice 10 (2) (2016): 250-271.

56 'McGuinness' missing victims vow', The Express, 9 May 2007, http://www.express.co.uk/news/uk/6581/McGuinness-missing-victims-vow (accessed 27 January 2017).
} 
books. While McGuinness may not have disavowed the IRA campaign, he was nonetheless prepared to acknowledge that 'the IRA carried out some indefensible actions resulting in the deaths of innocent people'.$^{57}$

The most instructive example is his comments during a speech at a peace conference marking the $20^{\text {th }}$ anniversary of the IRA's Warrington bombing:

As a republican leader it would be hypocritical of me to seek to distance myself from the consequences of armed struggle or the IRA's role in it. Nor can I or would I attempt to excuse the human loss caused by the IRA bomb in Warrington... it's shameful that two young boys lost their lives... Regrettably, the past cannot be changed or undone. Neither can the suffering, the hurt or the violence of the conflict be disowned by republicans or any other party to the conflict. ${ }^{58}$

Inherent in McGuinness' comments are 'self-critical' emotions through the expression of shame and regret at the killings, and 'other-suffering' emotions like empathy which can be understood as 'the ability to identify with the experiences and situation of another ${ }^{59}$ or, more simply put, attempting 'to take the other person's perspective' ${ }^{60}$ Here McGuinness may have chosen to adopt Cooley's 'looking-glass self' to understand how someone in his position would appear to IRA victims when encouraging them to 'move on'. ${ }^{61}$

In the same speech McGuinness also added:

The challenge for all of us engaged in the peace process... is to ensure that there can never be a repeat of what went before. We must learn the lesson of history; we

\footnotetext{
57 Gerry Moriarty, 'Martin McGuinness insists he left IRA in 1974', Irish Times, 20 September 2011, < https://www.irishtimes.com/news/martin-mcguinness-insists-he-left-ira-in-1974-1.603970> (accessed 3 November 2017).

58 Right World Comms, supra n 52.

${ }^{59}$ Hutchison \& Bleiker, supra $\mathrm{n} 30$.

60 Jan de Vries \& Jacinta de Paor, 'Healing and Reconciliation in the L.I.V.E. Program in Ireland', Peace \& Change, 30 (3) (2005): $329-358$.

${ }^{61}$ Charles H Cooley, Human Nature and the Social Order (New York: Routledge, 2017).
} 
must build a durable and just peace... Peace building, like conflict, is a joint enterprise. I challenge all of the parties to the conflict to pledge their commitment to the type of acknowledgment, respect and compromise we need to move forward in the years ahead. ${ }^{62}$

McGuinness is striking a redemptive tone here in recognising the need to repair hurt and build the peace further. ${ }^{63}$ In doing so, he is demonstrating 'future focused' emotions that are ground in loyalty to the future.

Away from the public eye, McGuinness was also 'other-suffering' too. This is demonstrated in the following account of a meeting he had with a victim whose brother was shot dead by the IRA. Recollecting the encounter the victim said:

I was at a meeting in Stormont.... Edwin Poots [Unionist politician] introduced me mentioning how my brother was shot by the IRA. McGuinness asked me if he had been killed, when I told him he was, he said he was sorry to hear that... he approached me afterwards and said "god bless you Ronnie". He gave me the impression he was being genuine, so I bear him no ill will. ${ }^{64}$

Even if McGuinness did not disavow IRA violence, on the occasions examined above he was able to display empathy and compassion in recognising the hurt that republicans had inflicted on others without trying to qualify this with an ideological defence of that violence. Accordingly, he had shown remorse by not trying to rationalise or justify past acts. ${ }^{65}$

\footnotetext{
${ }^{62}$ De Vries \& de Paor, supra $\mathrm{n} 60$.

${ }^{63}$ Brewer, supra n 28, 135.

64 "I feel pity for McGuinness' says IRA victim's brother', News Letter, 18 January 2017, http://www.newsletter.co.uk/news/i-feel-pity-for-mcguinness-says-ira-victim-s-brother-1-7779157/amp (accessed 27 January 2017).

${ }^{65}$ Pumla Gobodo-Madikizela, 'Remorse, Forgiveness, and Rehumanization: Stories from South Africa', Journal of Humanistic Psychology, 42 (1) (2002): 7 - 32.
} 
Having briefly outlined McGuinness' transformation from IRA commander to 'driver' of transition, attention now turns to the (un)changing moral emotions felt towards him by different audiences. More specifically, it will interrogate his moral-emotional relationship during 'transitional justice moments' with victims of the IRA and with the broader Irish republican constituency.

\section{McGuinness as blameworthy 'terrorist'}

Victims have become increasingly visible and vocal in transitional justice discourses. ${ }^{66}$ The 'moral authority of the victim' thus acts as a proxy indicator of how (un)fair the transitional process is. ${ }^{67}$ Seemingly they are in a unique position to make moralistic calculations of what is good and bad, what is right and wrong and what is just and unjust. Accordingly, they become the 'moral beacons' that set the parameters for how inclusive or exclusive and how restorative or retributive the processes for dealing with their victimisers should be. ${ }^{68}$ Victims, however, are not a monolithic constituency nor do they speak with a single voice ${ }^{69}$ Victims with differing views of 'moving on' can be (mis)used by those who drive or challenge transition. ${ }^{70}$ On the one hand there is the 'forgiving victim' who is favoured in official transitional justice discourses due to their more tolerant approach to the 'moving on' agenda. ${ }^{71}$ In contrast to this is the 'unreconciled victim' who favours retribution and exclusion. ${ }^{72}$ This 'resentful victim' is unwilling, perhaps even unable, to 'move on' with their

\footnotetext{
66 Juan Mendez, 'Victims as Protagonists in Transitional Justice,' International Journal of Transitional Justice 10 (1) (2016): 1-5; Kieran McEvoy \& Kirsten McConnachie, 'Victims and Transitional Justice: Voice, Agency and Blame', Social \& Legal Studies 22 (4) (2013): 498 - 513.

67 Jamieson, supra n 13, 182.

68 John Brewer \& Bernadette Hayes, 'Victimhood status and public attitudes towards post-conflict agreements: Northern Ireland as a case study', Political Studies, 61 (2) (2013): 442 - 461.

69 Tristan Borer, 'A Taxonomy of Victims and Perpetrators: Human Rights and Reconciliation in South Africa', Human Rights Quarterly 25, (4) (2003): 1088 - 1116.

70 Tshepo Madlingozi, 'On Transitional Justice Entrepreneurs and the Production of Victims', Journal of Human Rights Practice, 2 (2) (2010): 208 - 228.

${ }^{71}$ Kieran McEvoy, Ron Dudai \& Cheryl Lawther, 'Criminology and Transitional Justice' in The Oxford Handbook of Criminology ( $6^{\text {th }}$ ed) eds., Alison Leibling, Shadd Maruna \& Lesley McAra (Oxford: Oxford University Press, 2017), 403.

72 Michael Ure, 'Post-Traumatic Societies: On Reconciliation, Justice and the Emotions', European Journal of Social Theory, 11 (3) (2008): 283 - 297.
} 
victimiser and believe they have a right to be resentful towards them ${ }^{73}$ - particularly so if their victimiser is seen to have evaded what they interpret to be 'justice'. ${ }^{74}$

Negative moral emotions directed at McGuinness by 'unreconciled victims' of IRA violence include anger, understood as the emotional response to the actions of others that are 'judged unfair and unjust $^{\prime},{ }^{75}$ and resentment, which can be understood as the feeling that a past wrong has not been righted. ${ }^{76}$ Underpinning this is the betrayal of their moral expectations of how their victimiser would be treated during transition. ${ }^{77}$ Where their expectation was that victimisers like McGuinness would be punished, shamed and excluded, the outworking of the transitional process in the North of Ireland has instead included and legitimised McGuinness as a bona fide political actor. This exacerbated the anger felt by one of the Shankill bombing victims upon the retirement of McGuinness: 'our politicians are falling over each other to wish him well, have they forgotten already who he is and what he has done?'. ${ }^{78}$

With McGuinness asking to be judged by his 'deeds', for some victims of IRA violence his personal investment in the transition was sufficient to tentatively reconfigure their moral-emotional relationship with him, yet for others it was not. For such victims any initial commitment to the transition needs to be subsequently followed by some further action that will legitimise them as victims and delegitimise McGuinness as victimiser. ${ }^{79}$ This usually requires the victimiser to cede ground in relation to the legitimacy of their ideological cause rather than simply expressing regret

\footnotetext{
73 Panu Minkkinen, 'Ressentiment as Suffering: On Transitional Justice and the Impossibility of Forgiveness', Law \& Literature, 19 (3) (2007): $513-531$.

${ }^{74}$ Elster, supra n 28.

75 Turner \& Stets, supra n 32, 554

${ }^{76}$ Trudy Govier, Forgiveness and Revenge (London: Routledge, 2002), 50.

77 Mihai, supra n 13, 40.

78 Leona O'Neill \& Rebecca Black, 'Troubles victims who will not forgive ill Martin McGuinness for suffering IRA inflicted', Belfast Telegraph, 23 January 2017, http://www.belfasttelegraph.co.uk/news/northernireland/troubles-victims-who-will-not-forgive-ill-martin-mcguinness-for-suffering-ira-inflicted-35389273.html (accessed 27 January 2017).

${ }^{79}$ de Vries \& de Paor, supra n 60.
} 
for certain past transgressions. ${ }^{80}$ Their victimisation needs to be framed in a particular way that fits with their own politico-moral worldview. ${ }^{81}$ Former combatants will, however, be resistant to delegitimizing their past violence in this way. ${ }^{82}$ While Irish republicans have collectively - and McGuinness personally - engaged in recognising the human cost of IRA violence, they also nevertheless avoided questioning the legitimacy of the IRA campaign. ${ }^{83}$ Thus even if victimisers can express a degree of remorse for the suffering of their victims they will not repudiate the ideological framework underpinning that violence which outlasts the physical conflict itself. ${ }^{84}$

This aroused anger in one victim of the Enniskillen bomb when McGuinness was praised for his role in the transition:

He's been hailed as this hero and statesman, [but] I still see him as Martin McGuinness, the terrorist whose organisation brutally murdered my father. I live in pain for the actions of his organisation. He legitimises what the IRA did and shows no remorse, and I find that very difficult to accept. ${ }^{85}$

Other victims have similarly made McGuinness the 'target' of negative moral emotions for what they see as evasiveness about his IRA past. While McGuinness admitted to being in the IRA, he failed to offer any further elaboration beyond this. ${ }^{86}$ This bred resentment among some victims who believed it exposed insincerity on McGuinness' part. One victims' spokesperson argued that McGuinness had 'further cheated' victims upon his death by 'dodge[ing] accountability [and] citing the IRA's Green

\footnotetext{
$80 \mathrm{lbid}$.

${ }^{81}$ Karstedt, supra $\mathrm{n} 28$.

${ }^{82}$ De Vries \& de Paor, supra $\mathrm{n} 60$.

83 Hearty, supra $n 44$.

${ }^{84}$ Subotic, supra, $\mathrm{n} 26$.

${ }^{85}$ Allen Preston, 'Ruthless Provo or builder of peace? Victims split over Martin McGuinness legacy', Belfast Telegraph, 21 January 2017, http://www.belfasttelegraph.co.uk/news/northern-ireland/ruthless-provo-orbuilder-of-peace-victims-split-over-martin-mcguinness-legacy-35385253.html (accessed 20 March 2017).

${ }^{86}$ Moriarty, supra n 57.
} 
Book' when it came to disclosing what he knew or what he did while in IRA. ${ }^{87}$ A victim of the Claudy bombing said on the occasion of McGuinness' retirement that they 'can't agree' with him 'being hailed now as a great champion of peace... because if he was truly a peacemaker he would have went over all the things he was involved in, talk to the people who have lost loved ones and told them why he did it'..$^{88}$

For 'resentful victims', then, McGuinness as blameworthy 'terrorist' is the 'target' of personally and vicariously directed 'other-critical' and 'past focused' negative moral emotions. The 'instigation' underpinning this is disapproval of both his IRA past and how he addressed this during the transition; anger at his initial involvement in political violence and resentment over his failure to disavow that violence, to divulge what he knew to the victims of it and perhaps even too for the perception that he had benefitted from it. Just like during past conflict, McGuinness' conduct during 'transitional justice moments' is that expected by them from a 'terrorist'. Their emotions are conditioned by loyalty to the past; loyalty to an ideological belief in the illegitimacy of McGuinness' cause and loyalty to the memory of lost loved ones. Cumulatively, then, these victims seem both emotionally and politically-morally grounded in the past - unchanged perceptions of what is or is not moral regarding McGuinness and his conduct and unchanged negative moral emotions towards him as their victimiser reinforce one another. Rather than recalibrating their moral-emotional relationship with McGuinness, these 'resentful victims' reinforced their pre-existing relationship with him and cemented his position on their politico-moral spectrum.

\section{McGuinness as blameworthy traitor}

If McGuinness as blameworthy 'terrorist' is the 'target' of blame and negative moral emotions for failing to disavow his IRA past, then, conversely, McGuinness as blameworthy traitor is the 'target' of

\footnotetext{
87 'Prayer service for IRA victims held in Fermanagh', BBC, 23 March 2017, http://www.bbc.co.uk/news/uknorthern-ireland-39368401 (accessed 23 March 2017).

${ }^{88}$ O’Neill \& Black, supra $\mathrm{n} 78$.
} 
blame and negative moral emotions from former comrades who see his involvement in 'transitional justice moments' as irreconcilable with that past. This highlights the quagmire faced by McGuinness when 'doing' transitional justice; there is the paradox of not going far enough for one's victims yet simultaneously going too far for some within one's own constituency. Within Irish republicanism this has caused fundamental ideological disagreement, contestation over the collective memory of the dead and heated debates on spoiler violence that all centre on the perceived (in)congruence between Sinn Fein's involvement in transition and the IRA's past armed struggle. ${ }^{89}$ Ideology, politics and emotion cumulatively determine whether transition is embraced or rejected by those engaged in political violence. ${ }^{90}$ While 'drivers' of transition like McGuinness have bought into transition and framed it as an extension of past struggle through peaceful means, spoilers have instead held firm to the 'ethos of conflict'. ${ }^{91}$ Political violence is thus seen as legitimate, both in the past when McGuinness himself exercised and endorsed it, and today when manifest as anti-GFA spoiler violence. When McGuinness engaged in 'transitional justice moments' like publicly condemning this violence he subsequently repositioned himself in the politico-moral imagination of critical former comrades.

Consequentially, McGuinness as blameworthy traitor becomes the 'target' of contempt, which can be conceptualised as a disadvantageous comparison that 'involves looking down on another and feeling morally superior' ${ }^{92}$ It is often a response to a perceived violation of communal moral codes like honour and group loyalty. ${ }^{93}$ McGuinness was thus depicted as being ideologically impure and tainted through his personal and political commitment to transition. He was subsequently referred

\footnotetext{
${ }^{89}$ Hearty, supra $\mathrm{n} 44$.

${ }^{90}$ Lawther, supra $\mathrm{n} 28$.

${ }^{91}$ Daniel Bar-Tal, 'Why Does Fear Override Hope in Societies Engulfed by Intractable Conflict, as It Does in the Israeli Society', Political Psychology, 2 (3) (2001): $601-627$.

92 Turner \& Stets, supra n 32, 554.

${ }^{93}$ Ibid.
} 
to as a 'one time republican now in the pay of the enemy', ${ }^{94}$ while his engagements with the British monarchy seemingly stood in contrast with what 'authentic republicans' would do. ${ }^{95}$ Such is the strength of this contempt that the person responsible for recruiting McGuinness into the IRA said it was 'by far the biggest [mistake]' they had made. ${ }^{96}$

Other negative moral emotions have been evident in hard-line attitudes towards McGuinness. These include disgust, which operates on the premise of ostracising a wrongdoer for their immoral behaviour, ${ }^{97}$ and betrayal, which can be understood as 'anger mixed with sadness' ${ }^{98}$ In McGuinness' case, these are 'past focused' moral emotions that juxtapose where he stood in the imagined politico-moral spectrum during past conflict and where he stood on that same spectrum during 'transitional justice moments'. Movement along that spectrum has been interpreted as movement away from a legitimate cause and from those who sacrificed themselves for it in the past. Thus when McGuinness stood beside the PSNI Chief Constable and the DUP leader to condemn Irish republican spoiler groups as 'traitors' this was seemingly tantamount to betraying former comrades dead and alive. ${ }^{99}$ In light of these remarks, one critic argued that McGuinness had 'no business' standing at the graves of dead IRA members during the traditional Easter commemorative season. ${ }^{100} \mathrm{His}$ engagement with the British monarchy provoked a similar response, with his presence at the gravesides of dead martyrs said to be 'a contamination of the sacred places where.... revered

\footnotetext{
${ }^{94} \mathrm{G}$. Jackson, 'Dissident republican criticises Martin McGuinness' toast to the queen', The Irish Times, 22 April 2014, http://www.irishtimes.com/culture/dissident-republican-criticises-martin-mcguinness-s-toast-to-queen1.1769151> (accessed 20 March 2017).

${ }^{95}$ Henry McDonald, 'Republicans should oppose Queen's visit to jail, says ex-IRA commander', The Guardian, 20 June 2014, https://www.theguardian.com/uk-news/2014/jun/20/republicans-should-protest-queenbelfast-jail-visit-martin-mcguinness (accessed 30 January 2017).

96 'Recruiting Martin McGuinness... My biggest mistake', The Pensive Quill, 18 January 2017, http://thepensivequill.am/2017/01/recruiting-martin-mcguinness-my-biggest.html (accessed 27 January 2017).

${ }^{97}$ Turner \& Stets, supra n 32, 553.

98 Ibid, 559.

${ }^{99}$ Hearty, supra n 44.

100 'McGuinness "no business" at Easter parade: RSF', Impartial Reporter, 9 April 2009, accessed online via http://www.impartialreporter.com/news/13850122.McGuinness 034 no business 034 at Easter par ade RSF/ (accessed 14 March 2017).
} 
patriots rest'. ${ }^{101}$ Evident, here, is the ostracising that lies at the heart of disgust; as someone who was now ideologically tainted and morally impure McGuinness had to be distanced - physically and discursively - from dead patriots in order to protect the purity of Irish republicanism and the sanctity of their sacrifice.

McGuinness as blameworthy traitor can then be seen as the 'target' for negative moral emotions by former comrades who blame him for a sell-out of ideological principles, the struggle of the past and the sacrifice made by dead comrades. These moral emotions are 'other critical' and 'past focused'; they derive from loyalty to the past as manifest in loyalty to traditional ideology and loyalty to dead comrades. Just like 'resentful victims', these spoilers are emotionally and politically-morally grounded in the past - unchanged in their beliefs on the morality of political violence and unchanged in their emotional investment in dead comrades and their cause. Unlike 'resentful victims', though, the issue is with McGuinness of the recent past, not McGuinness of the distant past. The 'instigation' for negative moral emotions directed at McGuinness by critical former comrades arises from his repositioning on their imagined politico-moral spectrum; where he once stood in proximity to them in supporting Irish republican political violence, as a 'driver' of transition he ultimately came to stand at a distance from them. In short, where he was once a comrade during conflict he subsequently became a political enemy during transition. The 'objective', then, is to have McGuinness denounced as a traitor who can be distanced from uncompromising former comrades and the martyrs of the past. Essentially, approval of McGuinness during the conflict has given way to disapproval of him during the transition.

\section{McGuinness as creditable peacemaker}

Throughout the 'transitional justice moments' he was party to, Martin McGuinness openly recognised the difficulty his past had for those he was engaging with. However, in striving for a

\footnotetext{
${ }^{101}$ Alison Morris, 'RSF stay-away warning to 'Brit-loving' McGuinness', The Irish News, 15 April 2014, http://www.irishnews.com/news/2014/04/15/news/rsf-stay-away-warning-to-brit-loving-mcguinness-89145/ (accessed 14 March 2017).
} 
future free from past violence McGuinness exuded hope, understood as positive aspirations for a better future, ${ }^{102}$ during engagements with political opponents, the British monarchy and those allied against spoiler groups. While McGuinness may not have disavowed his past he did not seek to disown or disguise it either. Perhaps more so than any other figure associated with the conflict and transition, McGuinness led by example through 'owning' his past. For example, in 'owning' his past while 'doing' transitional justice McGuinness said of his engagement with the British monarchy:

I know who Queen Elizabeth represents. I know she's the head of the British state. I know she has all sorts of titles in relation to different regiments in the British Army. She knows my history. She knows I was a member of the IRA. She knows I was in a conflict with her soldiers, yet both of us were prepared to rise above all of that. ${ }^{103}$

While some of those British soldiers he alluded to maintained after McGuinness' death that he was a 'wretched man', ${ }^{104}$ others chose to see what was once a challenging enemy combatant on a 'different side' during the conflict becoming a fellow traveller in the process of making peace. ${ }^{105}$ Even former loyalist paramilitaries were prepared to see him through such a lens after he had publicly condemned spoiler violence. ${ }^{106}$

McGuinness' sincerity, coupled with expressions of regret and remorse, and demonstrations of empathy and compassion, also resonated with particular victims of the IRA that he had engaged

102 Daniel Bar-Tal et al., 'Collective Emotions in Conflict Situations: Societal Implications', Journal of Social Issues, 63 (2) (2007): $441-460$.

${ }^{103}$ Henry McDonald, "I like the Queen' says Martin McGuinness', The Guardian, 12 October 2014, https://www.theguardian.com/politics/2014/oct/12/martin-mcguinness-the-queen (accessed 30 January 2017).

104 John Monaghan, 'Former British soldier to return medal after being 'disgusted' at tributes paid to Martin McGuinness', Irish News, 22 March 2017, http://www.irishnews.com/news/2017/03/23/news/former-britishsoldier-to-return-medal-after-being-disgusted-at-tributes-paid-to-martin-mcguinness-973491/ (accessed 29 August 2018).

105 'Former British Army Soldier Hopkins Praises IRA General Turned Politician', KeighleyOnline, 21 March 2017, https://www.keighleyonline.co.uk/community/news/829-former-british-army-soldier-hopkins-praises-irageneral-turned-politician.html (accessed 29 August 2018).

${ }^{106}$ David Gordon, 'Top loyalist praises McGuinness but warns of 'Real UDA clowns', Belfast Telegraph, 12 March 2009, http://cain.ulst.ac.uk/victims/docs/newspapers/belfast telegraph/gordon_bt_120309.pdf (accessed 3 February 2017). 
with. While this fell short for some, as previously discussed, for others it evidenced the requisite emotional investment needed for furthering 'moving on' agendas. ${ }^{107}$ Their positive emotional response can be just as intense and powerful as the negative emotional response of 'resentful victims'. ${ }^{108}$ While McGuinness may have refused to condemn all IRA violence, by nonetheless exhibiting personal and collective 'self-critical' moral emotions while engaged with and in the presence of victims he had become sufficiently 'other-suffering' while trying to repair the damage caused by past violence. In doing so he stepped outside the Irish republican comfort zone in his redemptive approach. This was recognised by the father of one of the Warrington victims who said McGuinness deserved 'great credit' for venturing beyond the republican comfort zone in the cause of peacebuilding and, in so doing, 'put[ting] himself at some risk within some elements of his own community in Northern Ireland'. ${ }^{109}$ Similarly, a leading Protestant clergyman recognised this:

There was an honesty about him in that he never tried to avoid his past as a leading commander of the IRA in Derry... while acknowledging his past and the actions of others which led him into the IRA and the great loss of life his organisation caused very often to innocent civilians, it would be churlish not to commend and acknowledge his influence in the pursuit of peace... sometimes perhaps at great personal cost... his was the hand that was held out in friendship even to those who continued to see him as 'the enemy'. ${ }^{110}$

This nuances how McGuinness is the 'target' of moral emotions attributing blame and credit; while victims of IRA violence might not exonerate him from individual or collective blame for past violence, they are nonetheless prepared to credit him for his efforts in consigning that violence to the past.

${ }^{107}$ Goran Basic, 'Constructing 'Ideal Victim' Stories of Bosnian War Survivors', Social Inclusion, 3 (4) (2015): 25 $-37$.

108 de Vries \& de Paor, supra $\mathrm{n} 60$.

109 'Martin McGuinness: IRA survivors and their families speak out', BBC, 21 March 2017, http://www.bbc.co.uk/news/uk-northern-ireland-39337760 (accessed 21 March 2017).

${ }^{110}$ Patsy McGarry, 'Methodist Church praises Martin McGuinness's work for peace', Irish Times, 24 January 2017, < http://www.irishtimes.com/news/social-affairs/religion-and-beliefs/methodist-church-praises-martinmcguinness-s-work-for-peace-1.2949950> (accessed 25 January 2017). 
This is illustrated through Shankill bomb victim Alan McBride's observation that Northern Ireland 'owes a debt of gratitude' to McGuinness because while his 'fingerprints are all over the Troubles... they are also all over the peace process' ${ }^{111}$ Unionist politicians, too, were prepared to give McGuinness credit for where his journey ended. Ian Paisley Junior commented that McGuinness' work alongside his late father had taken him on a 'remarkable journey' that 'not only saved lives, but has made lives of countless people in Northern Ireland better' ${ }^{112}$ Indeed, Peter Robinson, who served as First Minister alongside McGuinness, recently remarked that had McGuinness been alive today the ongoing impasse between the DUP and Sinn Fein would have been resolved. ${ }^{113}$

There is a common convergence here between the moral emotions shown by Martin McGuinness during 'transitional justice moments' and those expressed above; both are characterised by 'future focused' emotions and both reflect loyalty to the future. While disagreement over the violent past may persist, in being sufficiently 'self-critical' and 'other-suffering' McGuinness became the 'target' of 'other-praising' moral emotions that afforded him credit as a peacemaker. Through his involvement in the transition, McGuinness as creditable peacemaker had changed his location on the imagined politico-moral spectrum of some victims and Unionists, transforming himself from an avowed political enemy to a fellow traveller in the process of bringing peace to Northern Ireland. In forging a new relationship of proximity that displaces the old relationship of distance, these victims and Unionists no longer set themselves up in competition to McGuinness as 'terrorist' but came to see themselves as sharing common ground with McGuinness as peacemaker. While they no doubt disapprove of McGuinness' earlier life, they nonetheless approve of the contribution he made to the transition during his later life. Although they are emotionally and politically rooted in the present

\footnotetext{
${ }^{111} B B C$, supra $\mathrm{n} 109$.

112 Julia Rampen, 'Watch lan Paisley Jr thank Martin McGuinness for partnership that 'saved lives", New Statesman, 20 January 2017, http://www.newstatesman.com/politics/staggers/2017/01/watch-ian-paisley-jrthank-martin-mcguinness-partnership-saved-lives (accessed 27 January 2017).

113 'Robinson "step back, take a breath and ensure there is sufficient space for an agreement to be reached in the calmer times that follow the hustings"', Slugger O'Toole, 1 March 2017, http://sluggerotoole.com/2017/03/01/robinson-step-back-take-a-breath-and-ensure-there-is-sufficient-spacefor-an-agreement-to-be-reached-in-the-calmer-times-that-follow-the-hustings/ (accessed 2 March 2017).
} 
and future, they may simultaneously be morally anchored in the past, present and future; while it would have been immoral to approve of McGuinness during the conflict, or similarly to approve of McGuinness' past during transition, it is now nevertheless moral to approve of him as someone working for a peaceful future during 'transitional justice moments'.

\section{McGuinness as elevated 'struggle hero'}

From the mid-1970s onwards the leadership of the (Provisional) Irish republican movement was defined by the constant presence of two pivotal figures; Gerry Adams and Martin McGuinness. ${ }^{114}$ Consolidating their control over that movement at the expense of traditionalists, they became the public faces of a movement that was rebalancing itself in favour of electoralism rather than militarism by the 1990 s. ${ }^{115}$ When the GFA was agreed in 1998 and Sinn Fein entered into a devolved powersharing government, the appointment of McGuinness as a governmental minister personified the discourse of former combatants transitioning into political activists to continue the armed struggle by peaceful means. ${ }^{116}$ For those supportive of Sinn Fein McGuinness represented a 'struggle hero' - an iconic figure synonymous with community and cause. ${ }^{117}$

Naturally, then, there was a tangible sense of loss at the death of McGuinness. Black flag vigils were held throughout republican communities. ${ }^{118}$ While there was a naturally sombre feel to this there was, too, a sense of paying tribute to a leader. This reflects the positive moral emotion of pride that communities with experience of political conflict can feel in their leaders. ${ }^{119}$ To this end, the emotion of elevation, essentially thankfulness to someone seen to bravely make sacrifices for others, ${ }^{120}$ characterised the Sinn Fein discourse on McGuinness. This elevation had predated his death, with

\footnotetext{
${ }^{114}$ Richard English, Armed Struggle: The history of the IRA (Oxford: Oxford University Press, 2004).

115 Kevin Bean, The New Politics of Sinn Fein (Liverpool: Liverpool University Press, 2007).

116 Hearty, supra n 44.

117 Sabine Marschall, 'Commemorating 'struggle heroes': Constructing a genealogy for the new South Africa', International Journal of Heritage Studies, 12 (2) (2006): 176 - 193.

118 'Martin McGuinness: Vigils held for Sinn Fein leader', BBC, 21 March 2017, http://www.bbc.co.uk/news/uknorthern-ireland-39344909 (accessed 28 March 2017).
}

${ }^{119}$ Cardenas et al., supra n 28.

${ }^{120}$ Turner \& Stets, supra n 32, 556. 
Michelle O'Neill saying upon replacing him as Sinn Fein leader in the North that it was 'a huge honour' to be following in the footsteps of a 'political giant' ${ }^{121}$ It became complete upon his death when many members of Sinn Fein replaced their social media profile pictures with pictures of McGuinness. Such is the strength of the 'struggle hero' framing of McGuinness that an IrishAmerican initiative advocating the principles of equality, respect, truth and self-determination that coincided with the $20^{\text {th }}$ anniversary of the GFA was posthumously named 'The McGuinness Principles'. ${ }^{122}$ Indeed, the unveiling of murals and memorial stones in various republican communities in the months following his death means that McGuinness the 'struggle hero' will be memorialised for future generations of Irish republicans to draw inspiration from. ${ }^{123}$ This might be the catalyst for an intergenerational transmission of collective positive moral emotions towards their 'struggle hero'.

In framing McGuinness as elevated 'struggle hero', the Sinn Fein discourse was keen to acknowledge his contribution to the transitional process in Northern Ireland but at the same time defend his role during the conflict. Thus McGuinness of the distant past and the recent past was legitimised as a morally righteous leader who always acted in the best interests of his community - whether defending them militarily or leading them through peaceful politics.

Rejecting assertions that McGuinness had become some sort of latter-day repentant 'terrorist', Gerry Adams argued that he 'was not a terrorist' but a 'freedom fighter'. ${ }^{124}$ While 'resentful victims'

\footnotetext{
121 'Sinn Fein name Michelle O'Neill as new 'leader of the North' to succeed Martin McGuinness', Belfast Telegraph, 23 January 2017, http://www.belfasttelegraph.co.uk/news/northern-ireland/sinn-fein-namemichelle-oneill-as-new-leader-of-the-north-to-succeed-martin-mcguinness-35390697.html (accessed 15 March 2017).

122 'Martin McGuinness Principles', Friends of Sinn Fein, https://www. friendsofsinnfein.com/martinmcguinness-principles/ (accessed 29 August 2018).

123 'New mural in Ballinamore honours Martin McGuinness', Leitrim Observer, 2 April 2017, https://www.leitrimobserver.ie/news/local-news/243103/new-mural-in-ballinamore-honours-martinmcguinness.html (accessed 29 August 2018); 'Poignant Ceremony Reflects On Life of Martin McGuinness', Louth Sinn Fein, http://www.louthsinnfein.ie/news/3391/poignant-ceremony-reflects-on-life-of-martinmcguinness (accessed 29 August 2018).

124 'Martin McGuinness was 'freedom fighter, not terrorist', BBC, 23 March 2017, http://www.bbc.co.uk/news/uk-northern-ireland-39368451 (accessed 23 March 2017).
} 
sought to blame McGuinness for the destruction of the conflict, Adams portrayed him as a product, rather than a cause, of that conflict, saying 'Martin McGuinness never went to war, the war came to him. It came to his streets, it came to his city, it came to his community'. ${ }^{125}$ Accordingly, McGuinness had made a conscious, and in Adams' evaluation a morally sound, decision to engage in armed struggle on behalf of his community. Adams followed up his praise of the 'freedom fighter' McGuinness with praise for his pivotal role in moving Irish republicans from armed struggle to electoral politics:

Thanks to Martin we now live in a very different Ireland, which has been changed irrevocably. Without him, I don't think there could have been the type of peace process we've had - and much of the change we now take for granted could not have been achieved. His contribution to the evolution of republican thinking was enormous. ${ }^{126}$

Inherent in these statements is the sense that McGuinness had always acted in a morally righteous way when confronted with a political challenge - the challenge of engaging in armed struggle when that was necessary and the challenge of converting this into a peaceful political struggle when the opportunity arose. Indeed, McGuinness himself had reaffirmed this shortly before his death:

I am deeply proud of the generation of Irish republicans that came before us. A generation that kept the vision of freedom alive... I have been privileged to be part

\footnotetext{
125 'He didn't go to war, war came to him': Gerry Adams pays tribute to ally and friend Martin McGuinness', TheJournal.ie, 21 March 2017, http://www.thejournal.ie/martin-mcguinness-gerry-adams-3298380Mar2017/?utm source=twitter self (accessed 23 March 2017).

${ }^{126}$ Gerry Adams, "Yesterday, Ireland lost a hero' - Gerry Adams', An Phoblacht, 22 March 2017, http://www.anphoblacht.com/contents/26752 (accessed 23 March 2017).
} 
of the generation that broke the apartheid state apart and to have been part of a Sinn Fein leadership that delivered peace and radical change. ${ }^{127}$

This chimes with the Sinn Fein discourse on the transitional process in Northern Ireland, one premised on the belief that while they may not have achieved their political aims through armed struggle they did nonetheless manage to bring down a discriminatory state and to win status as equal citizens in the post-conflict state which is in itself an apposite building block to eventually realise their core ideological goal. ${ }^{128}$ This point was consistently made by McGuinness himself when he frankly acknowledged that it remains my own personal and political ambition to break the link with Britain and to unite all who share this island under the common banner of Irish men and women' ${ }^{129} \mathrm{He}$ even expressed this while 'doing' transitional justice, commenting in the aftermath of an engagement with the British monarchy that 'I went to the meeting as an Irish republican, I came away as a very proud Irish republican'. ${ }^{130}$ Indeed, according to Michelle $\mathrm{O}^{\prime}$ Neill, in continuing his past struggle politically by working the transition McGuinness had strengthened the republican cause and earned himself a place among 'the iconic republican leaders of the ages' ${ }^{131}$

McGuinness as elevated 'struggle hero' is therefore the 'target' of 'other-praising' positive moral emotions from his comrades in Sinn Fein who approve of his role during the conflict and during the transition. In the former he is credited with having selflessly taken up arms to defend his community and to bring down a discriminatory state. In the latter he is credited with having brought Irish republicans to a position of political strength and having subsequently brought the North of Ireland

\footnotetext{
127' In full: Martin McGuinness's statement on why he chose to leave politics now', The Journal, 19 January 2017, http://www.thejournal.ie/martin-mcguinness-statement-stepping-down-3195111-Jan2017/ (accessed 27 January 2017).

128 Bean, supra $\mathrm{n} 115$.

129 The Journal, supra n 127.

130 'A very nice meeting' - Martin McGuinness had a private audience with the Queen last night', The Journal, 24 June 2014, http://www.thejournal.ie/martin-mcguinness-queen-elizabeth-private-meeting-1534605Jun2014/ (accessed 30 January 2017).

131 'We are forever thankful to Martin McGuinness', Sinn Fein, 23 March 2017, http://www.sinnfein.ie/contents/43970 (accessed 23 March 2017).
} 
into a new peaceful dispensation. There is an infusion here of loyalty to the past and loyalty to the future; there is adherence to the core ideological goals McGuinness always possessed yet there is also an aspiration that these can be reached today without political violence. This is replicated in their moral calculations; it was moral to use political violence in the past communal hour of need as McGuinness did but it is not moral to do so today in the new peaceful dispensation that McGuinness helped to bring about. The positive moral emotions expressed towards McGuinness the 'struggle hero' reflects their relationship of close proximity on the imagined politico-moral spectrum with him during both the conflict and transition.

\section{Conclusion}

The case of Martin McGuinness evidences the moral-emotional complexity of 'transitional justice moments'. While 'doing' transitional justice, he was simultaneously morally censured as an unrepentant 'terrorist', ostracised as a traitor, thanked as a peacemaker and exalted as a 'struggle hero'. This demonstrates the nuanced breadth of the 'emotional palette' found in transitioning societies. ${ }^{132}$ This nuanced emotional palette reflects positive moral emotions that credit McGuinness for his role in the transition and different positive moral emotions that credit him for his role during the conflict and the transition. However, at the same time, this same emotional palette also contains negative moral emotions that blame him for the devastation of the conflict and the injustice of the transition and other negative moral emotions that blame him for a sell out of an ideological cause. The conflict between these moral emotions reveals that the range of emotions in transitioning societies cannot be restricted to those that chime with official macro-level 'moving on' agendas and discourses. ${ }^{133}$

The resonance of such negative moral emotions exposes the subaltern narratives of 'resentful victims' and spoilers that are incongruent with 'transitional justice moments'. This mismatch derives

\footnotetext{
132 Ure, supra n 72.

${ }^{133}$ van Roekel, supra n 39.
} 
from mutually exclusive politico-moral frameworks that certain constituencies construct and subscribe to. 'Transitional justice moments', and those 'doing' transitional justice, are evaluated through these imagined politico-moral frameworks that are shaped simultaneously by the past, present and future. Accordingly, the 'target' can become repositioned along the imagined politicomoral spectrum of the 'judgemental self' dependent, of course, on who is making the judgement. Any such repositioning is contingent on an amalgam of factors that includes changes in identities, changes in relationships and changes in understandings of what is and is not moral in a transitional justice context. In McGuinness' case, whether his personal investment in 'transitional justice moments' is worthy of blame or credit will, however, invariably remain a calculation that is determined by his relationship with the varying permutations of the 'judgemental self' found in the North of Ireland. 